JAMP: Jurnal Adminitrasi dan Manajemen Pendidikan

Volume 4 Nomor 1 Maret 2021, Hal : 51 - 60

Tersedia Online di http://journal2.um.ac.id/index.php/jamp/

ISSN 2615-8574 (online)

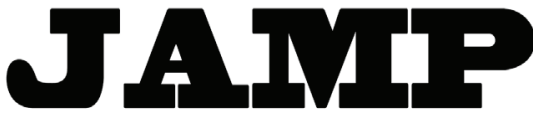

JURNAL ADMINISTRASI DAN MANAJEMEN PENDIDIKAN

\title{
EVALUASI KUALITAS JASA SEKOLAH DASAR DENGAN MODEL SERVQUAL UNTUK MENANGANI PENURUNAN JUMLAH PESERTA DIDIK
}

\author{
Gloria Jonathan \\ Ade Iriani \\ Universitas Kristen Satya Wacana- Jl. Diponegoro 52-60, Salatiga \\ gloriahuang100@gmail.com087780732125
}

\begin{abstract}
This study aims to evaluate the service quality of Kanaan Christian Elementary School in Banjarmasin. Type of research is evaluative research with descriptive qualitative methods using SERVQUAL model which measures the gap between consumer perceptions and expectations based on dimensions of reliability, responsiveness, assurance, empathy, and tangibility. Data were collected by interview, also using a SERVQUAL and school's input, process and output aspect questionnaire. The results showed that the perception of service from customers is quite good and able to meet the minimum expectations although it has not reached the desired expectations. The order of SERVQUAL's five dimensions from most satisfying to least satisfying is: tangibility, reliability, empathy, assurance, and responsiveness. It can be concluded that the dimension of responsiveness is in the most unsatisfactory position because currently the management of Kanaan Christian Elementary School in Banjarmasin seems like there is no one taking a leader role. Things that can be considered by Kanaan Christian Elementary School are to keep and prove the promise that has been delivered so that customers are not easily disappointed and also involve parents in a word of mouth marketing strategy due to the character of target customers are critical, like to gather and chat together.
\end{abstract}

Keywords: educational service; school quality; SERVQUAL

Abstrak: Penelitian ini bertujuan mengevaluasi kualitas jasa di SD Kristen Kanaan Banjarmasin. Jenis penelitian ini adalah penelitian evaluatif dengan metode kualitatif deskriptif menggunakan model SERVQUAL yang mengukur kesenjangan antara persepsi dan ekspektasi konsumen berdasarkan dimensi reliabilitas, daya tanggap, jaminan, empati, dan bukti fisik. Teknik pengumpulan data dengan wawancara, dibantu kuesioner berinstrumen SERVQUAL dan aspek input, proses dan output sekolah. Hasil menunjukkan bahwa persepsi layanan jasa dari pelanggan cukup baik dan cukup memenuhi harapan minimum walaupun belum mencapai harapan yang diinginkan. Urutan lima dimensi SERVQUAL dari yang paling memuaskan hingga yang paling tidak memuaskan adalah: bukti fisik, keandalan, empati, jaminan, dan daya tanggap. Disimpulkan dimensi daya tanggap berada di posisi paling tidak memuaskan adalah karena saat ini manajemen SD Kristen Kanaan Banjarmasin seolah seperti tidak ada yang mengambil peran pemimpin. Hal yang dapat menjadi pertimbangan SD Kristen Kanaan adalah agar dapat menjaga dan membuktikan janji yang telah disampaikan agar pelanggan tidak mudah kecewa dan dapat melibatkan orang tua murid dalam strategi pemasaran mulut ke mulut mengingat karakter target pelanggan yang kritis, suka berkumpul dan mengobrol.

Kata kunci: jasa pendidikan; kualitas sekolah; SERVQUAL 
Indonesia telah menjadi negara penghasil sektor jasa dalam beberapa tahun terakhir (BPS, 2019). Salah satu sektor jasa dalam hal pendidikan adalah sekolah. Namun, jika melihat sekolah sebagai bisnis, maka jumlah peserta didik merupakan hal yang amat krusial karena berperan dalam kelangsungan hidup sekolah, terutama untuk sekolah swasta yang sumber dana utamanya berasal dari peserta didik. Jika jumlah peserta didik sebuah sekolah tidak mencukupi, bisa saja menemui fenomena regrouping atau merger seperti SD Dukuh 04 dan SD Mangunsari 02 di Kota Salatiga, Jawa Tengah. Karena itu dalam menjalankan sekolah, manajemen peserta didik dan manajemen pemasaran merupakan hal yang penting. Manajemen peserta didik berhubungan dengan jumlah peserta didik yang menentukan efisiensi kegiatan belajar-mengajar di sekolah dan kualitas peserta didik setelah menempuh masa belajar. Sementara manajemen pemasaran meliputi aktivitas promosi, menjaga kualitas jasa pendidikan dan loyalitas pelanggan, agar pelanggan bisa setia dan tidak berpindah ke sekolah lain. Sebagai contoh, penelitian Margareta (2018) yang berjudul Strategi Pemasaran Sekolah dalam Peningkatan Minat Peserta Didik Berdasarkan Delta Model menyebutkan peserta didik yang tidak memenuhi kuota pada sekolah penelitiannya disebabkan oleh masalah manajemen pemasaran.

SD Kristen Kanaan telah berdiri sejak tahun 1992 dan telah menjadi sekolah favorit bertahuntahun di Banjarmasin, Kalimantan Selatan. Namun dalam beberapa tahun terakhir, data menunjukkan bahwa jumlah siswa baru beberapa tahun terakhir menjadi tidak stabil bahkan cenderung menurun. Survey pendahuluan menunjukkan bahwa hal ini mungkin disebabkan oleh adanya sekolah baru yang lebih dekat dengan daerah pemukiman warga, biaya pendidikan SD Kanaan yang tergolong mahal, juga adanya keraguan orang tua murid mengenai penurunan kualitas SD Kanaan, yang memungkinkan berkurangnya kepuasan dan loyalitas konsumen. Contohnya dalam sebuah penelitian di Iran, Mosahab (2010) menyebutkan bahwa banyak orang tua murid lebih memilih untuk mengeluarkan banyak uang untuk sekolah swasta karena mereka tidak puas dengan kualitas sekolah negeri, walaupun pendidikan sekolah negeri di Iran tanpa dipungut biaya.

Dalam upaya meninjau kepuasan konsumen akan kualitas layanan jasa, Parasuraman, Zaithaml, dan Berry pada 1990 berhasil mengidentifikasi dimensi pokok kualitas jasa yang juga menjadi dimensi dari model SERVQUAL, yaitu: (1) Reliability (keandalan) yang merupakan kemampuan untuk memberikan pelayanan sesuai dengan apa yang telah dijanjikan sebelumnya secara akurat dan terpercaya; (2) Responsiveness (daya tanggap), yaitu kemampuan untuk memberikan pelayanan yang responsive (cepat tanggap) dan tepat kepada pelanggan, juga memberikan informasi yang jelas; (3) Assurance (jaminan) yang merupakan kemampuan untuk menumbuhkan rasa percaya dan yakin dari pelanggan pada janji yang diberikan; (4) Empathy, yaitu perhatian yang tulus dan bersifat pribadi, yang menunjukkan bahwa perusahaan memahami konsumen; (5) Tangibility (bukti fisik), yaitu bukti nyata dari pelayanan yang diberikan, contohnya seperti fasilitas fisik (Parasuraman, et al, 2005). Sehingga pengukuran kesenjangan antara persepsi yang dimiliki konsumen dengan harapan mereka akan jasa tersebut inilah yang disebut dengan pengukuran kualitas jasa model SERVQUAL. Skor kesenjangan yang positif artinya persepsi melebihi ekspektasi dan pelanggan senang. Sementara skor kesenjangan yang negatif artinya persepsi yang diterima kurang dari ekspektasi, dan pelanggan tidak puas, dan tidak senang. Jika skor kesenjangan sama dengan nol, artinya persepsi pelanggan telah menemui ekspektasinya dan pelanggan puas (Hoffman dan Bateson, 2011).

Kualitas dalam sektor pendidikan, pemerintah mendorong Manajemen Berbasis Sekolah (MBS) dimana harapannya sistem pendidikan terbentuk melalui pendidikan yang bermutu, yang memampukan warga negara Indonesia menjadi manusia berkualitas yang dapat mengikuti tantangan perubahan zaman. Karena itu, menurut Nurkolis (2003), selain sekolah harus memiliki output yang diharapkan seperti halnya prestasi akademik dan non-akademik (olahraga, seni, nilai-nilai); sekolah juga harus memerhatikan proses seperti kegiatan belajar-mengajar yang efektif, kepemimpinan sekolah yang kuat, lingkungan sekolah yang aman dan tertib, evaluasi dan perbaikan secara berkelanjutan yang terus dilakukan sekolah, sekolah memiliki akuntabilitas dan berkomunikasi dengan baik, dll; dan juga input seperti memiliki kebijakan, sasaran mutu yang jelas, terdapat sumber daya yang kompeten dan berdedikasi tinggi, dapat berfokus pada pelanggan, dan lainnya. 
Jika kualitas jasa sudah baik dan membuat konsumen puas, maka customer value akan meningkat dan secara umum citra perusahaan (sekolah) akan dinilai baik, hingga akhirnya terciptalah pelanggan yang setia (Kotler \& Armstrong, 2016). Terdapat beberapa penelitian yang membuktikan adanya hubungan antara kualitas jasa dan loyalitas pelanggan. Fatona (2010) dalam penelitiannya akan dunia perbankan menemukan bahwa semakin variabel reliabilitas, daya tanggap, jaminan, empati, dan bukti fisik meningkat, maka nasabah yang ia teliti pun semakin loyal. Contoh lain adalah Penelitian Hwang dan Choi (2019) dengan judul Higher Education Service Quality and Student Satisfaction, Institutional Image, and Behavioral Intention yang juga menggunakan metodologi SERVQUAL di sebuah universitas swasta di Seoul. Hasil menunjukkan bahwa siswa puas dengan berbagai aspek kualitas layanan yang juga memengaruhi kepuasan siswa dan citra kelembagaan. Selain itu, hasil menunjukkan bahwa persepsi citra dan kepuasan institusional siswa secara langsung memengaruhi niat perilaku mereka.

Penelitian ini bertujuan untuk menganalisis jasa di SD Kristen Kanaan Banjarmasin dengan menggunakan SERVQUAL sehingga sekolah dapat melihat keunggulan dan kekurangan jasa. Sebagai respon, sekolah dapat melakukan tindakan perbaikan sehingga diharapkan ketidakpuasan pelanggan tidak berkelanjutan dan tidak akan berimbas pada loyalitas pelanggan atau penurunan input peserta didik baru, dan sekolah dapat terus bersaing dan mengatasi penurunan jumlah peserta didik.

\section{METODE}

Penelitian ini adalah penelitian evaluatif dengan metode kualitatif deskriptif menggunakan model SERVQUAL yang mengukur kesenjangan (selisih) antara persepsi dan ekspektasi konsumen berdasarkan dimensi reliabilitas, daya tanggap, jaminan, empati, dan bukti fisik. Penelitian kualitatif adalah metode untuk mengeksplorasi atau memahami makna, yang dapat menghasilkan kata-kata tertulis atau lisan dari data deskriptif yang dapat diamati, baik dari orang maupun perilaku (Bogdan dan Taylor dalam Moleong, 2012). Sementara penelitian deskriptif mendeskripsikan peristiwa dan kejadiaan saat ini dan memusatkan perhatian pada masalah aktual tersebut seperti pada saat penelitian dilaksanakan (Sudjana dan Ibrahim, 2009).

Teknik pengumpulan data dalam penelitian ini dilakukan dengan wawancara serta kuesioner dengan instrumen SERVQUAL yang juga berindikasi aspek input, proses dan output sekolah (Tabel 1) dengan kuesioner skala likert tujuh poin. Berikut adalah poin-poin atribut yang menjadi pertanyaan kuesioner dan panduan dalam wawancara yang dilakukan.

\section{Tabel 1. Atribut SERVQUAL pada Penelitian Ini}

\begin{tabular}{lll}
\hline No. & Dimensi & Butir Pertanyaan \\
\hline 1 & Keandalan (Reliability) & $\begin{array}{l}\text { Sekolah menyediakan jasa sesuai dengan yang dijanjikan } \\
\text { Dapat diandalkan dalam menangani masalah jasa pelanggan } \\
2\end{array}$ \\
3 & & $\begin{array}{l}\text { Proses belajar mengajar disiplin dan lancar } \\
\text { Guru memberi materi dengan baik dan sesuai }\end{array}$ \\
4 & & Sekolah mendorong dan membantu siswa mengembangkan potensi \\
5 & & Terbuka untuk membantu pelanggan \\
6 & Daya Tanggap & Memberi pelayanan yang cepat (tanggap) \\
7 & (Responsiveness) & Karyawan ramah dan sopan dalam menjelaskan / bekerja sama \\
8 & & Sekolah professional dalam menanggapi keluhan/masalah \\
9 & & Guru dan karyawan menumbuhkan rasa percaya \\
10 & Jaminan (Assurance) & Sekolah memberikan rasa aman dan terjamin \\
11 & & Sekolah bersikap adil pada semua siswa \\
12 & & Sekolah menempatkan guru terbaik yang cocok di bidangnya \\
13 & &
\end{tabular}




\begin{tabular}{lll}
\hline No. & Dimensi & Butir Pertanyaan \\
\hline 14 & Empati (Empathy) & Sekolah memberikan perhatian kepada siswa yang susah/belum memahami \\
15 & & materi pelajaran \\
16 & Guru memahami bahwa semua anak memiliki potensi masing-masing \\
17 & Sekolah sungguh-sungguh mengutamakan kepentingan bersama \\
18 & & Pihak sekolah yang memahami kebutuhan pelanggan \\
19 & Bukti Fisik (Tangibles) & Gaktu layanan sekolah yang nyaman \\
20 & & nyaman \\
21 & & Fasilitas kelas, laboratorium dan perpustakaan yang terawat \\
22 & & Guru dan karyawan yang berpenampilan rapi dan profesional \\
\hline
\end{tabular}

Yang menjadi subjek dalam penelitian ini adalah kepala sekolah, beberapa guru, beberapa orang tua murid, beberapa murid kelas 5, juga perwakilan dari manajemen. Analisis data menggunakan teknik SERVQUAL, dimana skor SERVQUAL dapat dihitung dengan rumus (Zeithaml, et. al., 1990): Skor SERVQUAL = Skor Persepsi - Skor Harapan. Selain itu analisa juga dilakukan dengan menghitung Zone of Tolerance (harapan yang diinginkan dikurangi dengan harapan minimum), Measure of Service Superiority (persepsi dikurangi nilai harapan yang diinginkan), dan Measure of Service Adequacy (persepsi dikurangi nilai harapan minimum) (Parasuraman, 2004). Dengan kata lain, Zone of Tolerance dapat disebut sebagai kisaran skala harapan pelanggan. Apabila persepsi pelanggan masih berada dalam zona ini, maka pelanggan masih puas. Tetapi jika persepsi di bawah Zone of Tolerance, maka pelanggan tidak puas bahkan mungkin merasa tertipu dan ingin berganti ke pilihan pemberi jasa yang lain (Nadiri, et. al., 2009). Validasi data yakni menggunakan triangulasi sumber dan triangulasi metode.

\section{HASIL DAN PEMBAHASAN}

Bagian ini dijabarkan menjadi delapan bagian, yakni dari pemaparan hasil persepsi pelanggan akan kualitas jasa saat ini, analisis MSS, analisis MSA, dan analisis lima dimensi SERVQUAL.

\section{Persepsi Pelanggan}

Dari data hasil kuesioner dengan rentang skor 1-7, diketahui bahwa persepsi kualitas jasa baik dari sisi murid maupun orang tua murid semuanya berada di atas poin 4.7 sehingga dapat disimpulkan kualitas jasa SD Kristen Kanaan Banjarmasin dipersepsikan baik. Menurut teori, apabila persepsi melebihi harapan, maka artinya pelanggan puas. Namun apabila persepsi lebih rendah dari harapan, artinya pelanggan tidak puas. Melihat rata-rata persepsi pelanggan ada di atas 4.7, maka dapat diprediksi pelanggan puas, namun perlu dibuktikan dengan data harapan pelanggan. Gambar 1 merupakan gambaran persepsi dari murid, orang tua murid, dan rata-rata dari tiap dimensinya.

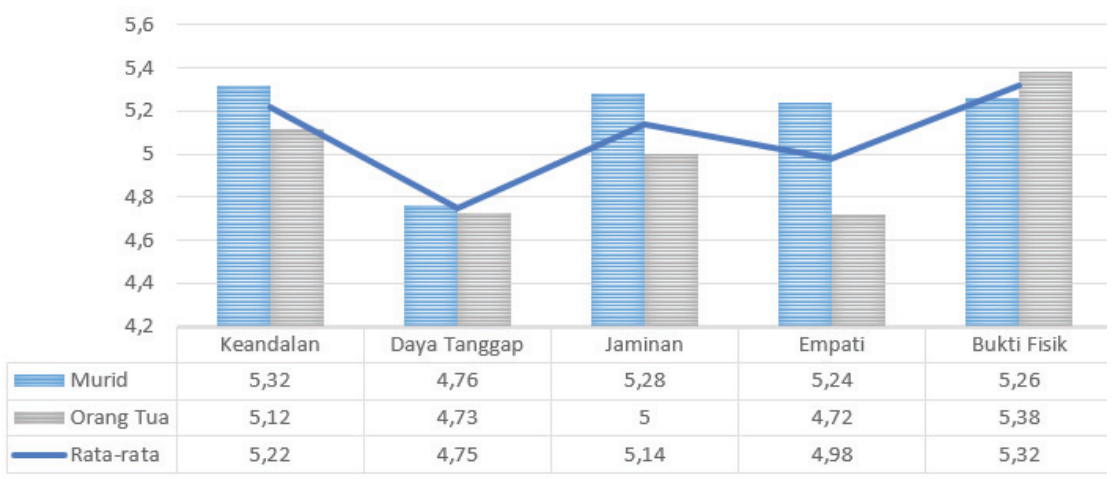

Gambar 1 Persepsi terhadap Layanan SD Kristen Kanaan Banjarmasin 


\section{Measure of Service Superiority}

MSS adalah rentang nilai harapan yang diinginkan dengan persepsi yang dirasakan saat ini. Dari Gambar 2 dapat dilihat bahwa skor persepsi murid dan orang tua murid di seluruh dimensi berada di bawah skor harapan yang diinginkan.

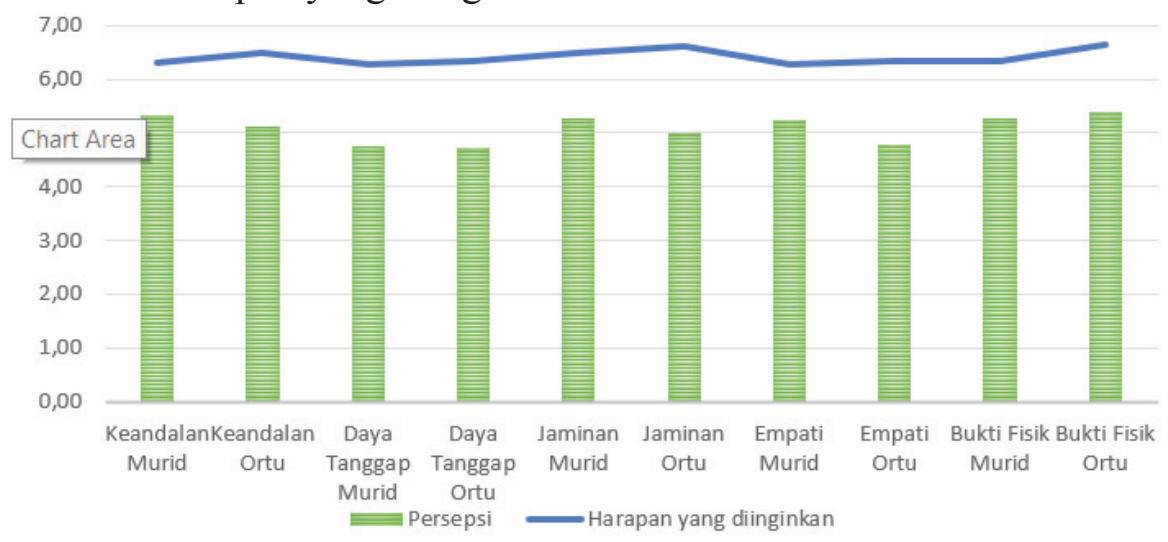

Gambar 2 Visual Gap MSS

Menurut teori SERVQUAL, hal ini menunjukkan pelanggan tidak puas akan layanan yang diberikan sekolah karena layanan yang mereka rasakan masih belum memenuhi ekspektasi yang diinginkan.

Sesungguhnya nilai persepsi layanan jasa dari pelanggan cukup baik, tetapi di saat bersamaan, harapan pelanggan juga terlampau tinggi. Hal ini kemungkinan disebabkan oleh karakteristik penduduk Kota Banjarmasin sendiri, juga status ekonomi sosial pelanggan SD Kristen Kanaan sendiri yang bisa dikatakan masyarakat menengah ke atas, di mana kebanyakan penduduk high-end di Banjarmasin akan memilih sekolah Kanaan. Karena harapan yang begitu tinggi, maka sukar untuk mencapai kepuasan pelanggan.

Hal ini sesuai dengan perkataan Kotler \& Armstrong (2016), dimana kunci untuk membangun hubungan pelanggan yang berjangka panjang adalah dengan menciptakan customer value dan kepuasan yang unggul. Penelitian ini dapat memetakan apa yang penting bagi customer, sehingga selanjutnya sekolah dapat mengambil tindakan yang mengarahkan pelayanan untuk memaksimalkan harapan pelanggan sehingga pelangan puas dan dapat terus bertahan. Oplatka \& Hemsley-Brown (2012) juga menyebutkan pemasaran di organisasi pendidikan harus didahului oleh riset, kemudian merumuskan strategi pemasaran dan menerapkannya, kemudian tidak lupa dievaluasi. Namun menurut wawancara, selama ini sekolah hanya meriset apakah siswa kelas 6 akan melanjutkan jenjang SMP di Sekolah Kanaan lagi atau tidak, yang artinya, riset tidak mengevaluasi kepuasan pelanggan dan tidak dapat memberikan gambaran untuk strategi pemasaran kedepannya.

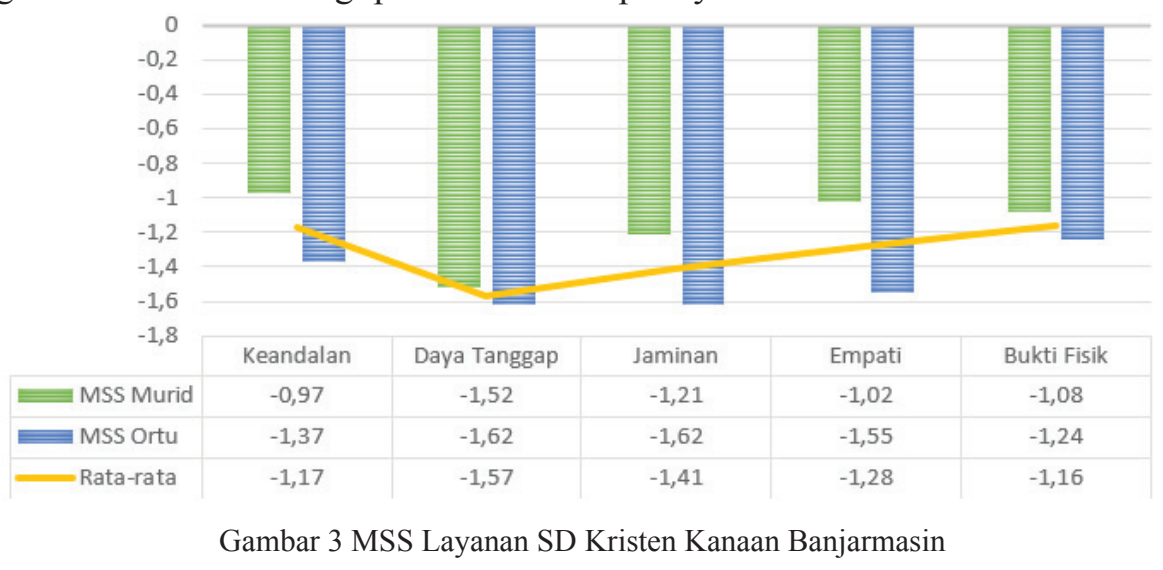

Dari Gambar 3 pun dapat kita lihat MSS di dimensi daya tanggap, jaminan dan empati bernilai negatif paling besar. Ini menunjukkan pelanggan lebih tidak puas pada tiga dimensi ini. Urutan persepsi dari yang paling baik adalah bukti fisik, keandalan, jaminan, empati dan daya tanggap. Meskipun ada 
perbedaan dengan urutan MSS, namun perbedaan tidak terlalu besar. Perbedaan paling terlihat adalah dimana persepsi jaminan lebih tinggi dari empati, namun MSS empati yang lebih baik dari jaminan. Hal ini dapat diartikan sebagai ekspektasi pelanggan akan empati memang tidak lebih tinggi dari jaminan, karena memang harapan yang diinginkan bagi dimensi jaminan adalah yang tertinggi dari seluruh dimensi SERVQUAL. Di bawah premis ini, persepsi yang diterima pelanggan membuat mereka merasa lebih puas akan layanan dimensi empati daripada dimensi jaminan. Walaupun nilai persepsi jaminan lebih tinggi daripada empati, namun dalam hati pelanggan, mereka merasa sudah seharusnya sekolah memberi layanan dimensi jaminan yang bisa lebih baik hingga mencapai nilai tertentu, yang ternyata tidak dapat direalisasikan sekolah sebagaimana harapan mereka. Hal ini membuat kekecewaan pelanggan pada dimensi jaminan lebih kuat.

\section{Measure of Service Adequacy}

MSA adalah rentang nilai harapan minimum dengan persepsi yang dirasakan saat ini. Nilai MSA akan lebih baik dari MSS, karena MSA mengukur harapan minimum yang lebih rendah dari harapan yang diinginkan. Gambar 4 dan 5 menunjukkan bahwa hampir semua item berada pada posisi positif, artinya kebanyakan pelanggan sesungguhnya masih dapat menerima kualitas layanan sekolah dan masih merasa puas, karena walaupun layanan jasa belum memenuhi harapan yang diinginkan, setidaknya sudah memenuhi harapan minimum pelanggan, kecuali dimensi daya tanggap dari sisi orang tua.

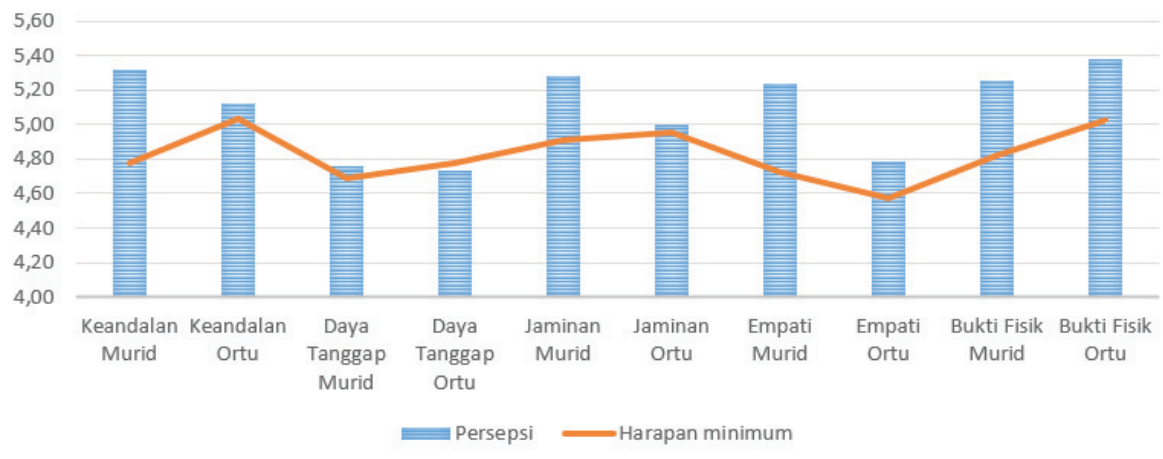

Gambar 4 Visual Gap MSA

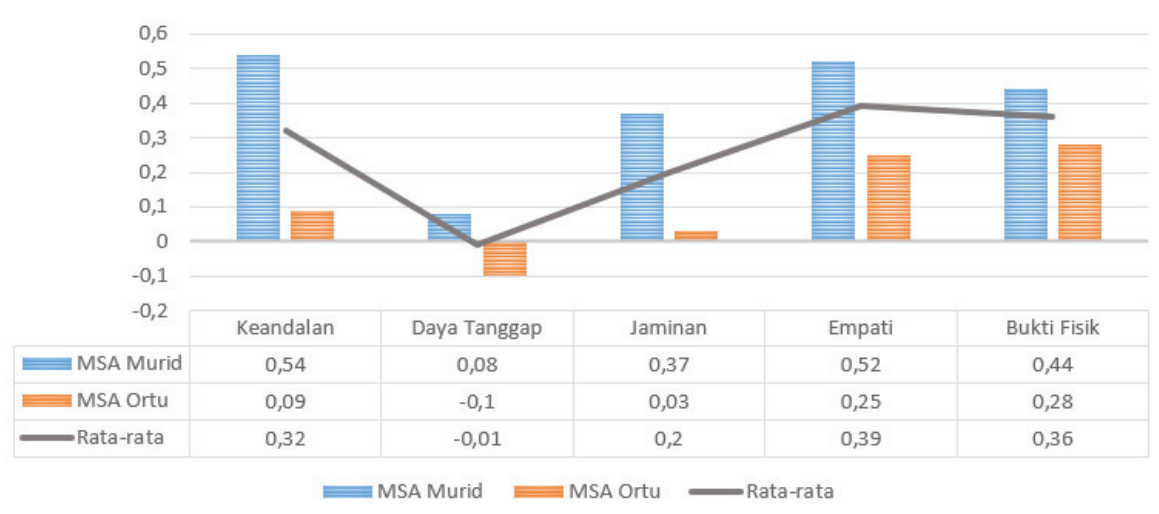

Gambar 5 MSA Layanan SD Kristen Kanaan Banjarmasin

\section{Analisis SERVQUAL Dimensi Keandalan}

Dimensi keandalan ada di urutan paling bagus ke-dua pada nilai persepsi dan MSS. Artinya, bagi pelanggan, keandalan SD Kristen Kanaan cukup memuaskan harapan mereka dan dinilai cukup baik kualitasnya. Skor rata-rata dimensi keandalan untuk persepsi sebesar 5.22 dan skor rata-rata untuk harapan yang diinginkan sebesar 6.39, dimana terdapat kesenjangan gap (MSS) sebesar -1.17.

Pada dimensi keandalan ini, kesenjangan terbesar adalah pada atribut "Proses belajar mengajar disiplin dan lancar" dengan nilai kesenjangan -1.34 dan nilai persepsi 5.03, yang artinya pelanggan merasa proses belajar mengajar sudah baik, walau mungkin masih belum begitu disiplin dan lancar sesuai harapan mereka. Hal ini dibuktikan juga dari hasil wawancara yang menyatakan bahwa sebenarnya SD 
Kanaan cukup tegas dan disiplin dalam proses belajar mengajar, seperti kelas tidak akan dibiarkan tidak terkendali bahkan kosong tak ada guru, juga apabila ada guru yang tidak dapat hadir untuk memberikan pelajaran, akan digantikan dengan guru pengganti yang tak hanya menjaga kelas, namun juga membantu memberikan pengajaran atau latihan soal bersama (wawancara, 6 Desember 2019).

Sedangkan atribut yang memiliki nilai kesenjangan terkecil adalah "Sekolah mendorong dan membantu siswa mengembangkan potensi" yang memiliki nilai kesenjangan sebesar -0.92 dan nilai persepsi 5.53. Hal ini juga didukung oleh hasil wawancara yang menyatakan bahwa sekolah menyediakan ekstrakurikuler yang beragam dan mencakup berbagai segi kecerdasan dan keterampilan, juga mendorong siswa-siswanya untuk mengikuti berbagai lomba dan pertandingan (wawancara, 5 Desember 2019).

\section{Analisis SERVQUAL Dimensi Daya Tanggap}

Dimensi Daya Tanggap berada di urutan paling terakhir, baik pada nilai persepsi dan MSS. Hal ini menunjukkan bahwa pelanggan beranggapan kualitas layanan SD Kristen Kanaan pada dimensi daya tanggap masih belum bagus dan sama sekali tidak sesuai dengan ekspektasi mereka, bahkan juga tidak memenuhi harapan minimum pelanggan. Skor rata-rata dimensi daya tanggap untuk persepsi sebesar 4.75 dan skor rata-rata untuk harapan yang diinginkan sebesar 6.32, dimana terdapat kesenjangan gap (MSS) sebesar -1.57.

Pada dimensi daya tanggap ini, kesenjangan terbesar adalah pada atribut "Memberi pelayanan yang cepat (tanggap)" dengan nilai kesenjangan -1.84 yang merupakan terburuk dari keseluruhan atribut, dan nilai persepsi 4.45 yang juga merupakan nilai persepsi terkecil dari keseluruhan atribut pertanyaan kuesioner SERVQUAL. Artinya, pelanggan merasa sekolah tidak tanggap dan lamban dalam memberi pelayanan. Sementara, pelanggan memiliki harapan yang tinggi untuk dilayani dengan cepat (tanggap). Sesungguhnya hal ini kurang tercermin dari hasil wawancara yang didapatkan. Dari wawancara diketahui bahwa apabila terjadi kecelakaan pada siswa di lingkungan sekolah, maka pihak sekolah bisa segera membawanya ke rumah sakit dan menghubungi orang tua terkait (wawancara, 5 Desember 2019).

Sedangkan atribut yang memiliki nilai kesenjangan terkecil adalah atribut "Terbuka untuk membantu pelanggan" dan "Karyawan ramah dan sopan dalam menjelaskan / bekerja sama" yang memiliki nilai kesenjangan yang sama yaitu sebesar -1.37 dan nilai persepsi berturut-turut 4.79 dan 5.08. Meskipun pada dimensi daya tanggap dua atribut ini tergolong lebih baik, namun secara keseluruhan pada instrumen SERVQUAL, dua atribut ini masih kurang baik dan kurang memuaskan. Dari hasil wawancara, diketahui bahwa pelanggan cukup puas dengan wali kelas, guru BP dan kepala sekolah yang mau mendengarkan keluhan dan masukan. Orang tua murid juga merasakan bahwa security dan petugas kebersihan sangat ramah dan proaktif untuk membantu, seperti security sebagai pagar pertama sekolah bersikap ramah dan sopan dalam membantu menerangkan pertanyaan lokasi atau tata cara yang perlu dilakukan sebagai tamu, juga bisa membantu menyebrangkan jalan (wawancara, 5 Desember 2019). Akan tetapi, juga diketahui saat menanyakan masalah di pertemuan orang tua murid, beberapa kali pihak manajemen merespon seperti lepas tangan dan melemparkan masalah ke yayasan pusat di Jakarta, sehingga pelanggan merasa pertemuan orang tua murid tidak efektif karena terkesan pihak sekolah tidak ingin membantu (wawancara, 6 Desember 2019). Dari pihak manajemen pun sempat menyinggung, bahwa manajemen sedang mengusahakan adanya Customer Relation Management (CRM) yang baik, karena memang akan lebih baik ada pihak khusus untuk menanggapi kritik dan saran dari pelanggan, namun karena wawancara pelamar jabatan ini dan pemilihannya dilakukan oleh yayasan pusat, maka orang yang terpilih kurang cocok untuk menangani masalah CRM di Banjarmasin, dan akhirnya mengajukan pengunduran diri untuk bekerja di tempat lain dan pada saat ini tidak ada yang memegang posisi ini (Bagian Personalia Tim Manajemen, wawancara, 6 Desember 2019).

\section{Analisis SERVQUAL Dimensi Jaminan}

Dimensi jaminan ada di urutan ke-tiga pada nilai persepsi dan urutan ke-empat terbaik pada MSS. Artinya, bagi pelanggan, jaminan SD Kristen Kanaan cukup baik kualitasnya, namun belum memenuhi harapan mereka untuk membawa kepuasan. Skor rata-rata dimensi jaminan untuk persepsi sebesar 5.14 
dan skor rata-rata untuk harapan yang diinginkan sebesar 6.55, dimana terdapat kesenjangan gap (MSS) sebesar -1.41 .

Pada dimensi jaminan ini, kesenjangan terbesar adalah pada atribut "Sekolah menempatkan guru terbaik yang cocok di bidangnya" dengan nilai kesenjangan -1.57 dan nilai persepsi 5.05 , yang artinya pelanggan merasa sekolah sudah cukup mengatur guru terbaik yang cocok di bidangnya, namun, berdasarkan yang didapat dari hasil wawancara dengan guru BK, diketahui masih belum sesuai harapan mereka. Hal ini didukung oleh hasil wawancara yang menyatakan bahwa memang guru dapat memberi kualitas pengajaran yang baik, namun ada beberapa guru yang cara mengajarnya kurang tepat jika berhadapan dengan anak-anak generasi alpha, terutama guru-guru senior, yang juga menjadi berimbas pada pembelajaran murid-murid (wawancara, 5 Desember 2019).

Sedangkan atribut yang memiliki nilai kesenjangan terkecil adalah "Sekolah memberikan rasa aman dan terjamin" dengan nilai kesenjangan sebesar -0.86 dan nilai persepsi 5.50, yaitu nilai gap terkecil dan nilai persepsi kedua terbesar. Hal ini juga didukung oleh hasil wawancara yang menyatakan bahwa karyawan (petugas kebersihan dan security) ramah dan memberi rasa aman, orang tua juga percaya untuk menitipkan anaknya ke petugas kebersihan selama belum dapat menjemput pulang sekolah (wawancara, 6 Desember 2019).

\section{Analisis SERVQUAL Dimensi Empati}

Dimensi empati ada di urutan ke-empat pada nilai persepsi dan ke-tiga pada MSS. Skor ratarata dimensi empati untuk persepsi sebesar 5.02 dan skor rata-rata untuk harapan yang diinginkan sebesar 6.30, merupakan angka harapan terendah dari semua dimensi SERVQUAL, dimana terdapat kesenjangan gap (MSS) sebesar -1.28. Artinya, pelanggan tidak terlalu menaruh begitu besar ekspektasi pada dimensi empati ini, namun layanan yang dipersepsikan pelanggan akan dimensi empati juga tidak begitu baik. Akan tetapi, nilai harapan minimum yang pelanggan inginkan untuk dimensi empati lebih rendah dibandingkan dengan dimensi lain, sehingga nilai MSA dimensi empati meraih nilai yang paling tinggi dari dimensi lainnya.

Pada dimensi empati ini, kesenjangan terbesar adalah pada atribut "Pihak sekolah yang memahami kebutuhan pelanggan" dengan nilai kesenjangan -1.50 dan nilai persepsi 4.71 yaitu persepsi terendah ketiga dari seluruh atribut kuesioner penelitian ini. Artinya, nilai kualitas layanan yang rendah ini masih berbeda cukup jauh dari harapan yang diinginkannya yaitu 6.21. Dengan kata lain, pelanggan masih tidak puas dengan merasa sekolah tidak memahami kebutuhan pelanggan. Dari wawancara, diketahui bahwa ada beberapa guru yang terkesan tidak peduli dengan siswa yang kurang mampu mengikuti pelajaran, asalkan guru tersebut dapat menyelesaikan pembelajaran tepat waktu sesuai yang direncanakan. Padahal menurut narasumber, terdapat pula murid yang membutuhkan perhatian khusus (wawancara, 6 Desember 2019). Juga diketahui kuesioner yang dibuat sekolah untuk evaluasi hanya dalam batassan apakah akan melanjutkan pendidikan di Sekolah Kanaan lagi, namun tidak bertanya lebih dalam mengenai kepuasan dan kebutuhan pelanggan.

Sedangkan atribut yang memiliki nilai kesenjangan terkecil adalah "Guru memahami bahwa semua anak memiliki potensi masing-masing" dan "Waktu layanan sekolah yang nyaman" dengan nilai kesenjangan sebesar -1.11 dan nilai persepsi berturut-turut sebesar 5.37 dan 5.21. Artinya guru sudah baik dalam melihat potensi siswa yang berbeda-beda, waktu layanan sekolah pun dinilai baik. Hal ini didukung hasil wawancara yang menyampaikan bahwa guru dan sekolah cukup mendorong siswa dari berbagai keterampilan, tak hanya akademik, juga non-akademik. Waktu sekolah pun cukup fleksibel, misal dengan pulang lebih awal saat masa ujian sehingga siswa bisa memiliki waktu belajar yang lebih nyaman di rumah, guru-guru yang selalu stand-by di kantor hingga sore jika dibutuhkan untuk ditemui, bahkan masih dapat dihubungi melalui Whatsapp hingga malam hari (wawancara, 6 Desember 2019).

\section{Analisis SERVQUAL Dimensi Bukti Fisik}

Dimensi bukti fisik berada di peringkat pertama baik pada nilai persepsi dan MSS. Skor rata-rata dimensi bukti fisik untuk persepsi sebesar 5.32 dan skor rata-rata untuk harapan yang diinginkan sebesar 6.49, dimana terdapat kesenjangan gap (MSS) sebesar -1.16, dengan skor harapan yang diinginkan dimensi ini merupakan tertinggi ke-dua dari keseluruhan dimensi SERVQUAL. 
Pada dimensi bukti fisik ini, kesenjangan terbesar adalah pada atribut "Fasilitas kelas, laboratorium dan perpustakaan yang terawat" dengan nilai kesenjangan -1.26 dan nilai persepsi 5.16, yang artinya pelanggan merasa fasilitas yang ada dirawat dengan cukup baik, walau masih belum memenuhi harapan mereka. Hal ini didukung hasil wawancara yang menyatakan bahwa terdapat beberapa komputer di laboratorium komputer rusak sehingga anak harus memakai satu komputer bersama-sama (berdua), sementara idealnya satu komputer digunakan oleh satu anak. Laboratorium bahasa pun kurang layak digunakan (wawancara, 6 Desember 2019).

Sementara atribut yang memiliki nilai kesenjangan terkecil adalah "Gedung, ruang kelas, laboratorium dan perpustakaan yang bagus dan nyaman", dengan nilai kesenjangan sebesar -1.05 dan nilai persepsi 5.37. Pada wawancara disampaikan bahwa meskipun sudah tua, namun gedung dan ruangan masih bagus. Namun pada wawancara juga diketahui ada beberapa toilet yang kenyamanannya terbengkalai. Namun ada pula orang tua murid yang menyatakan masalah toilet sudah ada perbaikan. Pihak manajemen pun merespon bahwa memang saat ini ada kendala dalam jumlah petugas kebersihan. Selain itu, dari wawancara diketahui bahwa Sekolah Kanaan sedang mencanangkan sekolah yang siap mengglobal dengan membuat sistem baru bernama Kanaan Next Gen. Salah satu yang diperhatikan pada Kanaan Next Gen ini adalah fasilitas ruangan kelas dengan standard sendiri, yang sudah diberikan percontohan sebanyak tiga kelas (wawancara, 6 Desember 2019). Hal ini pula yang kemungkinan besar membuat skor harapan terhadap dimensi bukti fisik menjadi yang terbesar kedua dari keseluruhan dimensi SERVQUAL.

Sehingga, urutan lima dimensi SERVQUAL dari yang paling memuaskan hingga yang paling tidak memuaskan adalah: bukti fisik, keandalan, empati, jaminan, dan terakhir daya tanggap. Disimpulkan dimensi daya tanggap berada di posisi paling tidak memuaskan adalah karena saat ini manajemen SD Kristen Kanaan Banjarmasin seolah seperti tidak ada yang mengambil peran pemimpin. Apabila dahulu keputusan dapat diambil langsung oleh yayasan setempat (yang saat ini disebut tim manajemen), saat ini harus melalui yayasan pusat di Jakarta. Sehingga untuk hal besar, tim manajemen menanggapi pelanggan dengan kesan melempar tanggung jawab ke tim pusat atau tidak menanggapi sama sekali.

Hal yang dapat menjadi pertimbangan SD Kristen Kanaan adalah tidak menambah nilai harapan pelanggan, apalagi dengan janji-janji yang belum tentu dapat direalisasikan. Mungkin mempromosikan program baru dari jauh-jauh hari akan bermanfaat di Sekolah Kanaan cabang lain, tetapi untuk pelanggan di Banjarmasin yang karakternya kritis, suka menuntut dan sering berkumpul mengobrol, hal ini bisa menjadi boomerang bagi sekolah apabila yang telah dijanjikan tidak dipenuhi dengan baik atau tidak sesuai standar mereka. Namun di sisi lain, sekolah juga dapat memberdayakan karakteristik pelanggan dengan menjalin hubungan yang baik dan menjadikan mereka duta sponsor bagi sekolah. Sekolah dapat menggunakan konsep word-of-mouth atau pemasaran dari mulut ke mulut, dengan premis memastikan pelanggan sejalan dan sepemikiran dengan sekolah sehingga apa yang mereka publikasikan dapat menguntungkan sekolah.

Dari hasil penelitian yang dilakukan telah ditemukan kelebihan kualitas jasa SD Kristen Kanaan, yaitu sebagai berikut: (1) Standar pengajaran Kanaan masih paling bagus se-Banjarmasin yang mana tiap tahun pasti mendapat prestasi di bidang akademik dan non-akademik, bahkan siswa terbaik seBanjarmasin juga dari Kanaan; (2) Pendidikan karakter SD Kristen Kanaan sangat baik, sehingga kemandirian, kedisiplinan dan kebiasaan nilai Kristiani terbawa sampai ke rumah; (3) Guru berkualitas, petugas kebersihan dan security ramah dan memberi rasa aman; (4) Sekolah sedang mengusahakan program terintegrasi untuk membantu komunikasi informatif transparan antar pihak sekolah dengan pelanggan.

Sementara kekurangan kualitas jasanya yaitu: (1) Penyampaian pengajaran guru senior kadang kurang cocok dengan siswa generasi alpha, guru juga dinilai kurang fasih berbahasa inggris; (2) Kebijakan pembiayaan sekolah dianggap kurang adil. Terdapat diskon khusus untuk jemaat, namun yang mendapatkan diskon adalah pelanggan dengan SES tinggi. Ada pula promo diskon besar namun diberikan kuota yang tidak dapat diterima positif karena pelanggan lebih mengutamakan mendapat diskon walaupun hanya sedikit. Juga tidak ada potongan biaya untuk siblings atau prestasi yang baik; (3) 
Kemampuan hubungan pelanggan sekolah masih kurang (saat ini posisi CRM sekolah sedang kosong) sehingga tak sedikit pelanggan merasa tersinggung dengan jawaban sekolah yang kurang bijak, atau karena sekolah banyak berjanji dan kurang terlihat hasilnya membuat pelanggan mudah kecewa.

\section{SIMPULAN}

Berdasarkan hasil penelitian dan analisis dapat disimpulkan bahwa persepsi layanan jasa dari pelanggan cukup baik dan cukup memenuhi harapan minimum. Akan tetapi, di saat bersamaan, harapan yang diinginkan pelanggan juga sangat tinggi. Hal ini dapat disebabkan oleh karakteristik penduduk Kota Banjarmasin juga status ekonomi sosial pelanggan SD Kristen Kanaan sendiri yang bisa dikatakan masyarakat menengah ke atas. Karena harapan yang begitu tinggi, maka sukar untuk mencapai kepuasan pelanggan.

Kelebihan kualitas jasa SD Kristen Kanaan saat ini cukup beragam dari hal prestasi akademis maupun non-akademis, Pendidikan karakter, SDM yang berkualitas, juga inovasi pengadaan program sebagai media komunikasi dengan pelanggan. Sementara kekurangannya ada dari segi kemampuan adaptasi guru dengan perkembangan zaman, kebijakan pembiayaan sekolah yang dirasa kurang adil, juga manajemen hubungan pelanggan yang masih kurang.

Diharapkan sekolah dapat mempertimbangkan dimensi-dimensi SERVQUAL sebagai acuan penyediaan jasa bali pelanggan. Selain itu sekolah juga perlu mendalami CRM, karena kunci untuk membangun hubungan pelanggan yang berjangka panjang adalah dengan menciptakan customer value dan kepuasan yang unggul.

\section{DAFTAR RUJUKAN}

BPS. (2019). Ekonomi Indonesia 2018 Tumbuh 5,17 Persen. Diakses dari https://www.bps.go.id/ pressrelease/2019/02/06/1619/ekonomi-indonesia-2018-tumbuh-5-17-persen.html, tanggal 1 Agustus 2019, pk. 03:40

Fatona, S. (2010). “Kualitas Jasa yang Mempengaruhi Loyalitas dan Relevansinya Terhadap Kepuasan”, Jurnal Dinamika Manajemen, Vol. 1, No.1

Hoffman, K. D., J. E. G. Bateson. (2011). Services Marketing: Concepts, Strategies, \& Cases, Fourth Edition. USA: South-Western

Hwang, Y.S., Y. K. Choi. (2019). "Higher Education Service Quality and Student Satisfaction, Institutional Image, and Behavioral Intention". Social Behavior and Personality An International Journal, Vol. 47, Issue 2

Kotler, P., G. Armstrong. (2016). Principles of Marketing. New Jersey: PEARSON

Margareta, R. T. E. (2018). "Strategi Pemasaran Sekolah Dalam Peningkatan Minat Peserta Didik Berdasarkan Delta Model". Magister Manajemen Pendidikan UKSW Salatiga.

Moleong, L. J. (2012). Metodologi Penelitian Kualitatif. Bandung: Remadja Rosdakarya.

Nadiri, H., Kandampully, J., \& Hussain, K. (2009). "Zone of tolerance for banks: a diagnostic model of service quality”. The Service Industries Journal, 29(11)

Nurkolis. (2003). Manajemen Berbasis Sekolah. Jakarta: Grasindo.

Oplatka, I., \& Hemsley-Brown, J. (2012). "Research on School Marketing: Current Issues Andfuture Directions - An Updated Version”. The management and leadership of educational marketing. Bingley, UK: Emerald Group Publishing.

Parasuraman, A. (2004). “Assessing and improving service performance for maximum impact: Insights from a two-decade-long research journey”. Performance Measurement and Metrics, 5(2), 45-52.

Parasuraman, A., V. Zeithaml, A. Malhotra. (2005). "E-S-Qual: A Multiple-Item Scale for Assessing Electronic Service Quality". Journal of Service Research. 7.

Sudjana, N., Ibrahim. (2009). Penelitian dan Penilaian Pendidikan. Bandung: Sinar Baru Algesindo

Zeithaml, V. A., A. Parasuraman, dan L.L. Berry. (1990) Delivering Quality Service. New York: The Free Press. 